\title{
PKM: PAUD PKK AI IKHSAN DESA PANGGUNGREJO WUJUD SINERGI DESA DAN PENDIDIKAN ANAK USIA DINI
}

\author{
Eny Yuniriyanti, Ririn Sudarwati, dan Totok Subianto \\ Fakultas Ekonomi dan Bisnis,Universitas Merdeka Malang \\ E-mail: eny.yuniriyanti@unmer.ac.id
}

\begin{abstract}
ABSTRAK. PAUD PKK AL IKHSAN Melayani program PAUD dengan Jenjang Kelompok Bermain (KB) dan Taman Kanak - Kanak (TK) yang bertempat di JL Pandan RT 03 RW 03 Dusun Tula'an Desa Panggungrejo, meskipun berada di wilayah Dusun Tula'an Namun PAUD PKK AL IKHSAN di upayakan dapat melayani 2 dusun yang lain yakni dusun panggung dan dusun tegaron yang berada dalam wilayah desa Panggungrejo. Permasalahan mitra diantaranya belum terurusnya ijin operasional lembaga dengan nama Lembaga baru karena perubahan Lembaga naungan, manajemen pengelolaan lembaga yang belum tertata dan perencanaan pembelajaran yang belum tersusun dengan baik. Metode yang digunakan dalam pelaksanaan program adalah pendampingan dan konseling penyusunan akreditasi PAUD, Memberikan Pelatihan pembuatan media pembelajaran dari bahan daur ulang, pelatihan metode pembelajaran yang kreatif dan inovatif berbasis pelatihan dan Mengadakan sosialisasi kepada masyarakat tentang pentingnya menyekolahkan anak usia dini. Dari hasil kegiatan peserta tidak hanya mampu mengisi secara manual setiap butir pada setiap standar ( 8 standart), tetapi juga cara mengunggah dokumen-dokumen tersebut secara on line karena pengajuan akreditasi PAUD dilaksanakan terpusat hanya dengan on line di SISPENA 2-0, untuk login menggunakan password yang dimiliki oleh masing-masing PAUD. Peserta mampu membuat media pembelajaran yang kreatif dan inovatif berbasis bahan dari daur ulang dan komputer. Dengan sosialisasi semakin banyak masyarakat yang mempercayakan anak usia dini dididik/ di sekolahkan di PAUD PKK Al Ikhsan
\end{abstract}

Kata Kunci: Akreditasi,media pembelajaran,sosialisasi

ABSTRACT. PAUD PKK AL IKHSAN Serves PAUD programs with Levels of Playgroups, and Kindergarten, which are located at JL Pandan RT 03 RW 03 Tula'an, Panggungrejo Village, even though they are in the Tula' an area but PAUD PKK Al IKHSAN is trying to be able to serve 2 other small village, namely Panggung and Tegaron which are in the area of Panggungrejo village. Partner problems include the lack of management of the institution's operational permit with the name of the new Institution because of changes in the Shade Institution, management of the institution that has not been organized and planning of learning that has not been well structured. The method used in the implementation of the program is mentoring and counseling for the preparation of PAUD accreditation, Training in the manufacture of learning media from recycled materials, training on creative and innovative computer-based learning methods and socialization to the public about the importance of sending early childhood education. From the results of the activity the participants were not only able to manually fill in each item in each standard, but also how to upload these documents on line because the PAUD accreditation application was carried out centrally only on line at SISPENA 2-0, to log in using password owned by each PAUD. Participants are able to create creative and innovative learning media based on materials from recycling and computers. With the socialization more people who entrust early childhood are educated in the PAUD PKK Al Ikhsan.

Key words: Accreditation, learning media, socialization

\section{PENDAHULUAN}

Pendidikan anak usia dini kerap disebut dalam Strategi Pendidikan 2020 Bank Dunia, yang memaparkan agenda 10 tahun ke depan di bidang pendidikan, dengan tujuan "Pembelajaraan untuk Semua". (Roesli R,2016). Pendidikan anak usia dini (PAUD) sangat strategis dalam pengembangan sumber daya manusia suatu bangsa. Tak hanya untuk menyiapkan tumbuh kembang anak menjadi sehat dan pintar, tapi juga berkarakter. Lahirnya UU No 6/2014 tentang Desa dan adanya dana besar yang akan masuk desa, posisi desa makin penting, termasuk pengembangan PAUD, untuk semua. Pedoman Umum PAUD Holistik yang terintegrasi yang dikeluarkan Kementerian Perencanaan Pembangunan Nasional/Bappenas 2009, menekankan pengembangan anak usia dini secara holistik-integratif. Institusionalisasi PAUD holistik yang terintegrasi bukan membuat layanan baru, melainkan bagaimana layanan yang sudah ada disinergikan dengan dengan menggerakkan kader pembangunan desa secara optimal, termasuk peningkatan pemahaman orang tua dalam tumbuh kembang anak. Mereka tak hanya mendampingi orang tua yang memiliki balita, tapi juga bisa dilatih meningkatkan kemampuan orang tua dalam pengasuhan dan tumbuh kembang anak. Sinergi aktivitas yang diprakarsai desa/kelurahan ini akan mampu menggerakkan semua potensi yang selama ini tidak optimal karena tidak ada aktivitas yang mampu menjadi jangkar untuk mereka berinteraksi (Mutaqin,2016).

Dalam kehidupan bermasyarakat banyak berkembang organisasi masyarakat yang didalamnya bertujuan untuk memberdayakan individu-individu yang diharapkan dapat menjadi panutan di tengah masyarakat dan dapat mengarahkan dirinya sendiri menjadi pribadi yang mandiri. Salah satu organisasi masyarakat yang ada di desa atau kota adalah PKK yang bertujuan memperdayakan perempuan agar dapat menjadi perempuan yang mandiri dan dapat membina keluarganya sesuai dengan visi Gerakan Pemberdayaan dan Kesejahteraan Keluarga selanjutnya disingkat PKK, yaitu "Terwujudnya keluarga yang beriman dan bertakwa kepada Tuhan Yang Maha Esa,berakhlak mulia ,sehat sejahtera, maju mandiri, 
kesetaraan dan keadilan gender serta kesadaran hukum dan lingkungan" (buku saku kader PKK,2007). PKK adalah gerakan pembangunan nasional dalam pembangunan masyarakat yang tumbuh dari bawah yang pengelolaannya dari, oleh dan untuk masyarakat. Pemberdayaan Keluarga, adalah segala upaya bimbingan dan pembinaan agar keluarga dapat hidup sehat sejahtera, maju dan mandiri (Soetomo, 2011). Kesejahteraan Keluarga, diartikan sebagai kondisi terpenuhinya kebutuhan dasar manusia dari setiap anggota keluarga secara material, sosial, mental dan spiritual sehingga dapat hidup layak sebagai manusia yang bermanfaat.PKK sebagai organisasi diharapkan bisa menjadi wadah potensial motor penggerak pembangunan khususnya dalam dalam hal pemberdayaan keluarga. PKK sebagai sebuah organisasi yang berbasis kepada keluarga dapat digunakan sebagai ujung tombak pembangunan.

Selama ini PKK sudah begitu melembaga baik di tingkat pusat, propinsi, kabupaten, kecamatan maupun desa. PKK dengan berbagai kegiatannya dalam pelaksanaannya telah merambah hingga tingkat dusun,RT dan Dasa Wisma melalui Pelaksanaan kegiatan 10 Program Pokok PKK ( buku saku kader PKK,2007 yaitu: 1. Penghayatan dan Pengamalan Pancasila; 2. Gotong Royong; 3. Pangan; 4. Sandang; 5. Perumahan dan tata laksana rumah tangga; 6. Pendidikan dan Keterampilan; 7.Kesehatan; 8. Pengembangan hidup berkoperasi; 9. Kelestarian lingkunan hidup; dan 10. Perencanaan Sehat.

Desa Panggungrejo merupakan sebuah desa di Kecamatan Kepanjen Kabupaten Malang, Jawa Timur, Desa panggungrejo memiliki 3 dusun yaitu Dusun Panggung, Dusun Tegaron dan Dusun Tula'an. Penduduk Desa Panggungrejo rata-rata adalah pendatang atau para urban yang berasal dari Malang Selatan, mengingat wilayah Panggungrejo merupakan daerah pinggiran Kota Kecamatan Kepanjen yang merupakan Kota Kabupaten Malang, sehingga banyak warga pendatang yang bertempat tinggal di desa Panggungrejo, perbedaan mata pencaharian antara penduduk asli dan pendatang memunculkan banyak masalah yang berimbas pada kesenjangan ekonomi dan kehidupan yang lain. Salah satu kesenjangan yang muncul adalah masalah pendidikan, dimana banyak terdapat anak usia dini yang tidak bersekolah di jenjang PAUD karena banyak warga yang merasa tidak penting menyekolahkan anaknya mulai dari jenjang PAUD, sehingga anak-anak tersebut tidak memiliki kegiatan yang jelas, sepanjang hari mereka hanya bermain-main saja bahkan di jalanan.

Terdapat 1 (satu) lembaga PAUD yang didirikan dan dikelola atas inisiatif ibu-ibu PKK Desa yang mengacu pada 10 program pokok PKK terutama program pendidikan dan ketrampilan sebagai perwujudan peran serta ibu ibu sebagai motor penggerak pembangunan khususnya dalam dalam hal pendidikan khususnya dan pemberdayaan keluarga pada umumnya. Lembaga PAUD PKK Desa Panggungrejo bernama AL IKHSAN yang Melayani program PAUD dengan Jenjang Kelompok Bermain ( KB) dan Taman Kanak-Kanak (TK) yang bertempat di JL Sumbersari Desa Panggungrejo, meskipun berada di wilayah Dusun Tula'an Namun PAUD PKK AL IKHSAN di upayakan dapat melayani 2 dusun yang lain yakni dusun panggung dan dusun tegaron yang berada dalam wilayah Desa Panggungrejo.

Eksistensi PAUD PKK AL IKHSAN yang ada di Desa Panggungrejo ini diharapkan bisa menjadi tempat bermain sambil belajar yang menyenangkan dan edukatif pada anak usia dini. Masa usia dini atau disebutmasa golden age dimana masa ini adalah masa emas pertumbuhan anak yang harus di prioritaskan perkembangannya semenjak lahir hingga usia pertumbuhan 4 tahun, sebagai mana amanat dalam Undang-undang SISDIKNAS bahwa salah satu tujuan Pendidikan non formal PAUD adalah mengembangkan potensi kecerdasan spiritual, intelektual, emosional, estetis, kinestetis, dan social peserta didik pada masa emas pertumbuhannya dalam lingkungan bermain yang edukatif dan menyenangkan.

Dibutuhkan pengetahuan yang lebih untuk orang dewasa untuk mengembangkan semua potensi pada anak secara maksimal. Orang dewasa dalam hal ini pendidik (guru) dan pengelola Lembaga PAUD (ibu-ibu PKK) membutuhkan kesempatan dan peluang peningkatan potensi dirinya dalam upaya mengembangkan potensi perkembangan anak secara maksimal. Oleh karena itu perlu di berikan pelatihan kaitannya dengan proses pembelajaran anak usia dini. Selain itu juga dapat membantu pengelola dan pendidik PAUD untuk melek informasi yang akan membawa pengaruh pada kreativitas pengembangan sarana pembelajaran untuk anak usia dini dalam pembelajaran di PAUD. Konsekuensinya, lembaga PAUD perlu menyediakan berbagai kegiatan yang dapat mengembangkan berbagai aspek perkembangan seperti: kognitif, bahasa, sosial, emosi, fisik, dan motorik.

Dalam menjalankan beberapa aspek diatas dibutuhkan tenaga pendidik (guru) yang paham tentang standar perkembangan, lembaga yang memiliki fasilitas sarana dan prasarana yang memadai sekaligus kurikulum yang terstandar untuk anak usia dini. Beberapa aspek diatas belum dimiliki oleh PAUD PKK AL IKHSAN, karena baru saja di tahun 2018 PAUD PKK AL IKHSAN baru saja mengalami peralihan pendampingan dari Lembaga yang lama menjadi pendampingan milik PKK Desa, sehingga semua harus di perbaiki lagi mulai dari pengurusan dari ijin Lembaga, pergantian nama Lembaga, sehingga dalam manajemen pengelolaan lembaga belum tertata secara maksimal karena mereka hanya bermodal pada prinsip yang penting anaknya sekolah dan ada proses belajar mengajar. Selain itu perencanaan pembelajaran juga belum terlaksana sesuai standar pembelajaran karena fasilitas yang belum memadahi. Selain itu upaya promosi penjaringan warga belajar terkendala dengan anggapan warga yang masih menganggap tidak pentingnya jenjang Pendidikan PAUD untuk anak mereka. Membaca situasi diatas perlu mendapatkan penanganan segera, agar segera tersolusi permasalahan di lapangan. 
Kegiatan Program Kemitraan Masyarakat (PKM) PAUD PKK Al Ikhsan dilaksanakan bersinergi dengan Sanggar Kegiatan Belajar (SKB) Kabupaten Malang. SKB sebagai lembaga pemerintah yang menyelenggarakan program-program PAUDNI (Pendidikan Anak Usia Dini Nonformal Informal) mencakup berbagai kegiatan layanan dan sasaran, salah satunya adalah: Layanan Pendidikan Anak Usia Dini: Kegiatan layanan pendidikan anak usia dini mencakup upaya-upaya :Menyelenggarakan PAUD bermutu dan berkesetaraan gender, melalui integrasi layanan pada satuan-satuan PAUD yang sudah ada, seperti Satuan Paud Sejenis (SPS) dengan jenjang: Taman Penitipan Anak (TPA), Kelompok Bermain (KB), dan Taman Kanak-kanak (TK).

\section{Permasalahan Mitra}

Berdasarkan observasi dan analisis situasi di atas, permasalahan yang dihadapi PAUD PKK AL IKHSAN adalah sebagai berikut :

1. Kompetensi dan keterampilan tenaga pendidik belum memenuhi standar akreditasi lembaga.

Kreatifitas para pendidik pada PAUD dianggap perlu dan penting dikarenakan anak-anak usia 0-6 tahun pada dasarnya masih senang bermain daripada harus belajar duduk di kelas dari pagi sampai siang (Depdiknas. 2006). Maka dari itu, walaupun pendidik pada PAUD sudah memiliki kualifikasi pendidikan yang cukup dan dapat menguasai bahan ajaran yang ditentukan, tetapi kurang mampu mengemasnya dalam kegiatan belajarmengajar kepada peserta didik, mengakibatkan peserta didik akan cepat bosan dan tentunya bahan ajaran yang disampaikan tidak akan diterima dengan baik oleh perserta didik.

2. Metode pembelajaran yang belum inovatif Sampai saat ini PAUD pada jalur formal dan non formal belum mempunyai kurikulum tetap yang ditetapkan oleh pemerintah, sehingga masing-masing lembaga PAUD harus menyusun sendiri dengan baik metode pembelajaran yang efektif sesuai dengan kondisi dan keberadaannya.Pada taraf PAUD metode yang banyak digunakan adalah metode belajar sambil bermain, karena lewat bermain, anak tidak merasa dipaksa untuk belajar. Dalam pelaksanaan metode pembelajaran belajar sambil bermain PAUD PKK Al Ikhsan tidak berjalan efektif karena sarana pembelajaran yang terbatas dan cara penyampaian materi pembelajaran yang kurang menarik

3. Sarana dan prasarana sebagai media pembelajaran yang terbatas

Kurangnya sarana dan prasana penunjang pendidikan sangat mempengaruhi pelaksanaan proses kegiatan belajar mengajar. Hal tersebut bisa menghambat kreatifitas para pendidik sehingga pembelajaran terasa membosankan. Sarana dan prasarana pembelajaran yang dimiliki masih konvensional ( papan tulis, alat permainan dari kayu dan bahan ajar berupa poster), sedangkan sarana dan prasarana untuk bermain outdoor berupa jungkitan dan ayunan dalam kondisi kurang baik sehingga kurang aman untuk digunakan.

4. Keterbatasan kemampuan untuk penjaringan peserta didik baru.

Hambatan yang sering dijumpai didaerah pedesaan di mana masyarakat dipedesaan masih memiliki anggapan bahwa anaknya tidak perlu disekolahkan sampai ke Perguruan Tinggi, apalagi dimulai dari PAUD. Bagi mereka yang terpenting adalah bagaimana nantinya anak mereka dapat membantu perekonomian keluarga.

\section{METODE}

Permasalahan yang di hadapi lembaga mitra merupakan urgensi yang harus segera diselesaikan secara bertahap, dengan menggunakan Metode Pendampingan dan Konseling.

Adapun Solusi yang ditawarkan dalam pelaksanan Metode Pendampingan dan Konseling ini, antara lain :

1. Memberikan pendampingan penyusunan/pengisian dan pengajuan Akreditasi

2. Memberikan pelatihan tentang Manajemen Organisasi kepada pengelola lembaga PAUD PKK AL IKHSAN.

3. Memberikan Pelatihan pembuatan media pembelajaran dari bahan daur ulang kepada pendidik, wali murid dan pengelola lembaga dalam kegiatan parenting. Wali murid dilibatkan dengan tujuan mereka bisa membuatnya di rumah. Dengan pelatihan ini diharapkan pendidik lebih kreatif dan inovatif dalam pelaksanaan belajar mengajar sehingga tidak membosankan. Dengan bahan bekas yang seharusnya dibuang dan jadi sampah bisa diubah/disulap menjadi alat alat edukasi tanpa mengeluarkan banyak biaya

4. Memberikan Pelatihan metode pembelajaran yang kreatif dan inovatif berbasis komputer kepada para pendidik sehingga mereka mengetahui bagaimana cara memperkenalkan komputer pada anak yang membuat anak merasa senang dan nyaman dalam belajar. Program yang bisa digunakan adalah program animasi (software) yang bersifat edutainment yaitu perpaduan antara pendidikan (education) dan hiburan (entertainment). Selain itu edutainment mempunyai kemampuan menumbuh kembangkan kreatifitas dan imajinasi anak serta melatih saraf motorik anak, sehingga anak dapat belajar sambil bermain.

5. Melaksanakan Focus Group Discussion (FGD) antara pengelola, pendidik dan instansi terkait dengan tema pembahasan isu-isu kurikulum pendidikan anak usia dini.

Pada tahun 2010 pemerintah Indonesia, khususnya Menteri Pendidikan Indonesia memulai wacana tentang Pendidikan Berbasis Karakter, tetapi sampai saat ini lembaga PAUD belum mempunyai kurikulum tetap yang sudah distandarkan oleh pemerintah. 
6. Mengadakan sosialisasi kepada masyarakat tentang pentingnya menyekolahkan anak usia dini dengan cara memfaatkan kegiatan ibu ibu PKK seperti pada saat pelaksanan arisan dan posyandu di tingkat RW

\section{Langkah-langkah Pelaksanaan Kegiatan}

Pelaksanaan kegiatan pendampingan pada lembaga mitra adalah sebagai berikut :

1. Metode pendekatan menggunakan kegiatan pendampingan yang dilakukan secara berkala dan terjadwal

2. Penyampaian pelatihan di laksanakan sesuai dengan prioritas masalah

3. Kegiatan pelatihan dilaksanakan melalui focus group discussion (FGD)

Dalam melaksanakan kegiatan pendampingan pada lembaga mitra dibutuhkan langkah-langkah sehingga proses memecahkan permasalahan mitra dapat tersolusi secara cepat adalah sebagai berikut:

a. Menggunakan bentuk pendekatan yang sesuai yakni komunikasi persuasif

b. Penyampaian pelatihan dilakukan secara terstruktur maupun tidak terstruktur,

c. Menyiapkan sarana dan prasarana yang dibutuhkan yakni modul, papan tulis, buku panduan, laptop, LCD, alat peraga maupun poster.

d. Menyiapkan modul pelatihan

e. Metode pelatihan menggunakan dua arah (diskusi), kelompok diskusi, pendampingan dan ceramah.

\section{HASIL DAN PEMBAHASAN}

\section{Implementasi Pelaksanaan Kegiatan}

1. Pendampingan penyusunan/ pengisian instrumen akreditasi dengan harapan keberadaan PAUD PKK lebih diakui dan lebih dapat mengakses bantuan dari pemerintah daerah maupun pusat dalam pembinaan maupun pembiayaan.,

Sebagai narasumber: adalah seorang Asessor PAUD sehingga lebih memahami cara pengisian instrumen akreditasi dan kelengkapan lampiran lampiran yang diperlukan. Peserta tidak hanya diajarkan cara mengisi secara manual setiap butir pada setiap standar (8 standart), tetapi juga cara mengunggah dokumendokumen tersebut secara on line karena pengajuan akreditasi PAUD dilaksanakan terpusat hanya dengan on line di SISPENA 2-0, untuk login menggunakan password yang dimiliki oleh masing-masing PAUD. Pendampingan dilaksanakan di PKBM Sumber Ilmu dengan pertimbangan di tempat tersebut tersedia wifi, sehingga setiap peserta bisa langsung praktek login SISPENA 2.0 dengan dipandu oleh narasumber.

2. Memberikan pelatihan tentang Manajemen Organisasi PAUD

Pengelolaan adalah suatu proses perencanaan, pengorganisaian, kepemimpinan dan pengendalian

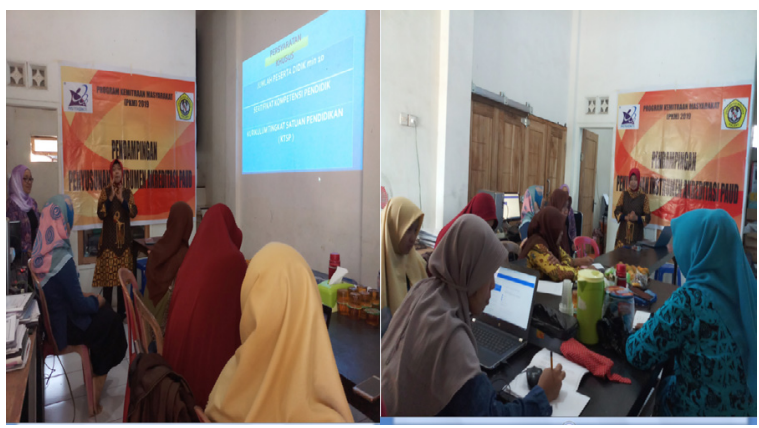

Gambar 1. Pendampingan penyusunan akreditasi

upaya anggota organisasi dimana keempat proses tersebut mempunyai fungsi masing masing untuk mencapai suatu tujuan organisasi. Dalam pendidikan anak usia dini juga harus adanya pengelolaan yang baik dan sesuai dengan ketentuan-ketentuanya.Suyadi (2011) menyatakan bahwa: Pengelolaan Pendidikan anak usia dini mempunyai tujuan meningkatkan dan memaksimalkan segenap daya pendidikan sehingga mampu mencapai tujuan, dan sebagai acuan pelaksanaan penyelenggaraan pendidikan disekolah sekaligus sebagai alat evaluasi penyelenggaraan kegiatan baik selama pengelolaa berlangsung maupun akhir tahun pembelajaran.

Kegiatan dilaksanakan bersamaan dengan kegiatan pendampingan penyusunan instrumen akreditasi PAUD

3. Memberikan Pelatihan pembuatan media pembelajaran dari bahan daur ulang

Kegiatan ini melibatkan para wali murid dengan tujuan mereka bisa membuatnya di rumah, karena dengan bahan bekas yang seharusnya dibuang dan jadi sampah bisa diubah/disulap menjadi alat alat edukasi tanpa mengeluarkan banyak biaya.

4. Memberikan Pelatihan metode pembelajaran yang kreatif dan inovatif berbasis komputer

Media pembelajaran merupakan sub sistem dari sistem pembelajaran, jika tidak disediakan maka akan terdapat kesenjangan dalam mencapai tujuan pembelajaran, seperti terjadinya perbedaan persepsi terhadap materi pembelajaran yang berakibat hasil belajar murid tidak optimal. Media pembelajaran dipilih oleh guru sesuai dengan tujuan pembelajaran dan dapat dimanfaat oleh murid di dalam kelas maupun di luar kelas sesuai dengan kegiatan yang akan dilakukan. Perkembangan media pembelajaran sangat beragam. Media Penyaji yaitu media yang mampu menyediakan informasi, misal gambar, poster, foto (yang digunakan sebagai alat peraga), transparasi, radio, telepon, film, televisi, multimedia (kit). Media objek yaitu media yang informasi sepewrti realita, replika, modul benda tiruan. Media interaktif yaitu media yang memungkinkan untuk berinteraksi selama mengikuti pembelajaran, misal scrabble, puzzle, laboratorium atau komputer.

Selain taksonomi media pembelajaran yang harus diperhatikan oleh guru, kriteria media media pembelajaran 
antara lain:1) Sesuai dengan tujuan pembelajaran yang ingin dicapai.(2) Tepat untuk mendukung materi pembelajaran.(3) Praktis, luwes dan tahan lama.(4) Guru terampil menggunakannya.(5) Jumlah peserta didik.(6) Mutu teknis media pembelajaran seperti ketersediaan energi listrik, cahaya di dalam ruagan.

Guru diharapkan tidak memilih media karena suka dengan media tersebut. Media yang dipilih adalah media yang diperlukan oleh murid.

5. Melaksanakan Focus Group Discussion (FGD) antara pengelola, pendidik dan instansi terkait dengan tema pembahasan isuisu kurikulum pendidikan anak usia dini. Kurikulum 2013 Pendidikan Anak Usia Dini dikembangkan dengan sejumlah landasan filosofis yang memberikandasarbagipengembanganseluruhpotensianak agar menjadi manusia Indonesia berkualitas sebagaimana yang tercantum dalam tujuan pendidikan nasional. (https://filepaudpintar.blogspot.co.id/)

Struktur Kurikulum Pendidikan Anak Usia Dini merupakan pengorganisasian muatan kurikulum, Kompetensi Inti, Kompetensi Dasar, dan lama belajar.

\section{Muatan Kurikulum}

Muatan kurikulum Pendidikan Anak Usia Dini berisi program program pengembangan yang terdiri dari:

1. Program pengembangan nilai agama dan moral mencakup perwujudan suasana belajar untuk berkembangnya perilaku baik yang bersumber dari nilai agama dan moral serta bersumber dari kehidupan bermasyarakat dalam konteks bermain.

2. Program pengembangan fisik-motorik mencakup perwujudan suasana untuk berkembangnya kematangan kinestetik dalam konteks bermain.

3. Program pengembangan kognitif mencakup perwujudan suasana untuk berkembangnya

4. kematangan proses berpikir dalam konteks bermain.

5. Program pengembangan bahasa mencakup perwujudan suasana untuk berkembangnya kematangan bahasa dalam konteks bermain.

6. Program pengembangan sosial-emosional mencakup perwujudan suasana untuk berkembangnya kepekaan, sikap, dan keterampilan sosial serta kematangan emosi dalam konteks bermain.

7. Program pengembangan seni mencakup perwujudan suasana untuk berkembangnya eksplorasi, ekspresi, dan apresiasi seni dalam konteks bermain.

\section{Kompetensi Inti}

Kompetensi Inti Kurikulum Pendidikan Anak Usia Dini merupakan gambaran pencapaian Standar Tingkat Pencapauan Perkembangan Anak pada akhir layanan Paud.

Kompetensi Inti mencakup:

1. Kompetensi Inti-1 (KI-1) untuk kompetensi inti sikap spiritual.
2. Kompetensi Inti-2 (KI-2) untuk kompetensi inti sikap sosial.

3. Kompetensi Inti-3 (KI-3) untuk kompetensi inti pengetahuan.

4. Kompetensi Inti-4 (KI-4) untuk kompetensi inti keterampilan.

\section{Kompetensi Dasar}

kemampuan awal anak serta tujuan setiap program pengembangan. Kompetensi Kompetensi Dasar merupakan tingkat kemampuan dalam konteks muatan pembelajaran, tema pembelajaran, dan pengalaman belajar yang mengacu pada Kompetensi Inti. Rumusan Kompetensi Dasar dikembangkan dengan memperhatikan karakteristik dan Dasar dibagi menjadi empat kelompok sesuai dengan pengelompokkan kompetensi inti yaitu:

1. Kelompok Kompetensi Dasar sikap spiritual dalam rangka menjabarkan KI-1

2. Kelompok Kompetensi Dasar sikap sosial dalam rangka menjabarkan KI-2

3. Kelompok Kompetensi Dasar pengetahuan dalam rangka menjabarkan KI-3

4. Kelompok Kompetensi Dasar keterampilan dalam rangka menjabarkan KI-4.

\section{Lama Belajar}

1. Lama belajar merupakan keseluruhan waktu untuk memperoleh pengalaman belajar yang harus diikuti anak dalam satu minggu, satu semester dan satu tahun. Lama belajar pada PAUD dilaksanakan melalui tatap muka

2. Kegiatan tatap muka di PAUD dengan lama belajar sebagai berikut.

a. kelompok usia lahir sampai 2 (dua) tahun dengan lama belajar paling sedikit 120 menit per minggu;

b. kelompok usia 2 (dua) tahun sampai 4 (empat) tahun dengan lama belajar paling sedikit 360 menit per minggu; dan

c. kelompok usia 4 (empat) tahun sampai 6 (enam) tahun dengan lama belajar paling sedikit 900 menit per minggu.

d. Satuan PAUD untuk kelompok usia 4-6 tahun yang tidak dapat melakukan pembelajaran 900 menit per minggu wajib melaksanakan pembelajaran 540 menit dan ditambah 360 pengasuhan terprogram

6. Sosialisasi kepada masyarakat tentang pentingnya menyekolahkan anak usia dini Pentingnya PAUD Bagi Pengembangan Pendidikan Masyarakat.

Pemerintah berperan aktif dalam pengembangan pendidikan di masyarakat melalui Dikmas dan Paud dengan mewujudkan Satu Desa Satu Paud. Undangundang Nomor 20 Tahun 2003 tentang Sistem Pendidikan Nasional Pasal 1 angka 14 menyatakan bahwa Pendidikan Anak Usia Dini (PAUD) adalah suatu 
upaya pembinaan yang ditujukan kepada anak sejak lahir sampai dengan usia enam tahun yang dilakukan melalui pemberian rangsangan pendidikan untuk membantu pertumbuhan dan perkembangan jasmani dan rohani agar anak memiliki kesiapan dalam memasuki pendidikan lebih lanjut. Dalam penerimaan murid baru didasarkan seleksi usia dan tidak dibenarkan melalui tes.

Dalam perkembangannya masyarakat telah menunjukan kepeduliannya terhadap masalah pendidikan, pengasuhan, dan perlindungan anak usia dini untuk usia 0 sampai 6 tahun dengan berbagai jenis layanan sesuai dengan kemampuan yang ada, baik dalam jalur pendidikan formal maupun nonfornal, contohnya PAUD PKK yang dikelola oleh ibu ibu PKK di Desa Panggungrejo

Beberapa Alasan strategis mengapa PAUD penting dan perlu bagi perkembangan anak:

1. Memenuhi hak anak untuk tumbuh dan berkembang secara baik

2. Mengoptimalkan masa emas perlembangan anak

3. Meningkatkan kesiapan anak bersekolah

4. Meningkatkan efisiensi pendidikan, menurunkan angka mengulang kelas, dan meningkatkan kemampuan anak untuk mengikuti pendidikan lebih tinggi

5. Jangka panjang: a) meningkatkan produktivitas kerja, kesejahteraan hidup, penerimaan pajak. (b) menurunkan angka kejahatan dan pengangguran

6. Sebagai investasi sumber daya manusia (human capital)

Setelah penyampaian materi dibagikan kuisioner untuk mengetahui pendapat peserta tentang Pendidikan Anak Usia Dini - PAUD.

\section{Rangkuman hasil kuisioner sebagai berikut :}

Pendidikan tertinggi responden adalah Magister/S2 dan terendah SD serta sebagian besar berpendidikan SMA dan Sarjana/S1(67\%). Sebagian besar jumlah anak adalah dua orang anak (50\%) dan sebagian besar belum ada yang sekolah PAUD (77\%) 67\% responden sangat setuju, Paud mempersiapkan anak sebelum memasuki jenjang pendidikan dasar dan Paud membantu pertumbuhan dan perkembangan anak dan $33 \%$ setuju.
$83 \%$ responden sangat setuju, kegiatan ekstra kulikuler dapat meningkatan minat dan bakat anak dan Paud meningkatkan kemampuan bahasa anak 17\% setuju. $83 \%$ responden sangat setuju, Paud meningkatkan kemampuan motorik anak dan Paud meningkatkan kemampuan anak dalam beradaptasi dengan teman, membantu teman dan berbagi dan $17 \%$ setuju.

\section{SIMPULAN}

Pelaksanan seluruh program kegiatan kemitraan berjalan dengan lancar karena partisipasi mitra baik pengolala maupun pendidik Paud yang bersedia secara aktif mengikuti pelatihan dan kegiatan pendampingan dalam upaya perbaikan lembaganya . Dengan status terakreditasi dan metode pembelajaran yang kreatif inovatif akan semakin banyak masyarakat yang mempercayakan anak usia dini dididik/ di sekolahkan di PAUD PKK Al Ikhsan. Selanjutnya keberlanjutan dan keberhasilan pelaksanaan program di lapangan setelah kegiatan PKM selesai adalah dengan menyerahkan kepada PKK Desa Panggungrejo dibawah pengawasan Kepala Desa Panggungrejo.

\section{DAFTAR PUSTAKA}

Buku saku Kader PKK, Tim Penggerak PKK Kabupaten Garut tahun 2007.

Depdiknas. 2006. Pedoman Pembelajaran di TK. Jakarta

(https://filepaudpintar.blogspot.co.id/), diakses 12 Juli 2109

Muttaqin,Tatang.2016. Desa dan PAUD terpadu. Pendidikan di The Inter-university Center for Social Science Theory and Methodology (ICS) University of Groningen The Netherlands.

Roesli, Rofita.2016 .Pendidikan Anak Usia Dini di Pedesaan,kunci untuk menghidupkan Potensi Indonesia. World Bank Blog

Soetomo . 2011. Pemberdayaan Masyarakat . Pustaka Pelajar. Yogyakarta 